\title{
TJETIPOIDT
}

\section{The State Land Trust, Its Retention or Elimination}

\section{G. WESLEY BURNETT}

Recommendation 106 of the Public Land Law Review Commission stated that:

Limitations originally placed by the Federal Government on the use of grant lands, or funds derived from them, should be eliminated. ${ }^{1}$

There is evidence that heated public and political debate on the merits of this recommendation is forthcoming. ${ }^{2}$ This paper reviews the nature of limitations placed on state land use, and the arguments of those favoring and opposing implementation of Recommendation 106.

\section{Limited Use of State Grant Lands}

Congress has generally required that each new state acknowledge federal sovereignty over unsettled land prior to admission to the Union. This acknowledgement has reduced the tax base of the new state and has forced the cost of public institution development on residents of the longest standing. To lessen this inequitable burden, Congress has traditionally granted land to the new states for the support of public institutions and vital improvements.

The grant process has involved the conveyance of specified lands in support of "common schools." In addition, statehood generally has empowered the state to select lands in lieu of school lands not actually available as well as additional land for the support of other institutions.

The salient aspects of this process are the lands' dedication to the support of particular institutions and that the dedication exists as a sacred trust between the state and Congress. Implicit is the understanding that the granted land should be managed to make money for the beneficiaries. Neither Congress nor the new state may alter the agreement established by statehood without the consent of the other. To Congress, this means that it may pass any law with respect to the grant lands, but that the law is meaningless unless the state concurs. To the state, without Congressional consent, no new land management innovation can be implemented unless it produces revenues. The state, of course, may pass laws necessary to manage the lands so long as the laws do not violate the trust concept either conceptually or specifically.

The specific terms of the trust were sparse in the initial land grant states. Abundant abuses could be expected, but without restrictions in the original trust there was little that Congress could do to assuage the often frightening waste of the grant lands. Since Congress could learn

The author is with the Parks Division, Montana Department of Fish and Game. Manuscript received July 18, 1977.

'Public Land Law Review Commission. 1970. One Third of the Nation's Land. Recom mendation 106.

'For example, in Montana, recent Legislative debate has centered around the opening of state trust land to recreational use as well as the reservation of selected lands as "natural" areas. Allowing noncompensatory recreational use of state lands has been considered in the 43rd and 44th Legislative Assembly and studied in the interim, but so far the debate has produced no successful legislation. The natural areas concept was approved by the 43rd Assembly and subsequently found by the Montana Attorney General to breach the trust as established in the Montana Constitution and Enabling Act. from its mistakes and provide assurances that the same abuses would not occur in subsequent land grants, land grants came to states in the West with more and more restrictions on their use. Most notably, Congress established stringent minimum sale prices and the procedures by which state grant land could be sold or leased.

Though the specific management rules have often been altered, the western states still retain substantial grant lands subject to both the general grant concept and the specific rules attached to it. Theoretically two dichotomous points of view may be taken concerning potential modification of this trust. At one extreme is that of the trustee. The trustee adheres to the concept of the trust as historically and presently good and worthy. It must be guarded against change. The other extreme is the point of view of the revisionist. To the revisionist the trust is a frontier anachronism which places unrealistic restraint on modern practices which benefit the entire public. The entire trust is a weight upon the shoulders of the land manager to be disposed of forthwith.

The positions of the trustee and the revisionist are theoretical extremes on a continuum of ideas, but future debate on Recommendation 106 is likely to center on these two theoretical positions as if no middle ground exists. The realist recognizes the existence of the extreme positions, but he also recognizes that the actual operation of the state lands has not, and probably will not, approach either theoretical extreme. Where the trustee and revisionist subscribe to their positions with religious and emotional fervor, the realist centers his concern about the trust's impact on actual and desired goals for state land management.

In the remainder of this paper, the rationale for and against the extreme positions is outlined, followed by an argument for a more realistic review of state land management goals. In essence, it is argued that too little is certainly known about the management of most state lands to substantiate the arguments of either the trustee or revisionist.

\section{The Trustee}

The trustee is conservative in his approach to the trust concept and understands it, regardless of its weaknesses, as an idea above reproach. Bert L. Cole, Commissioner of Public Lands in Washington, has recently given superb expression to this position. He writes:

I strongly believe the intent and purpose of the original grant of trust lands to the State should be protected at all levels. We should not allow a deterioration of our management responsibilities. . . . To do otherwise, in my opinion, would dilute my effective management as a trust officer. ${ }^{3}$

Cole obviously views himself as the guardian of a trust and as such may be incapable of addressing the broader questions concerning the social worth of that trust. Nonetheless, there is merit in his uncompromising position. Historically, if no other lesson has been

${ }^{3}$ Letter, Bert L. Cole, Commissioner of Public Lands, Washington Department of Natural Resources, to Leo Berry, Jr., Acting Commissioner, Montana Department of State Lands, December 28, 1976. 
learned, it is that state lands are easily abused either criminally or through failure to achieve intended management objectives. Further, there is the fear that opening the grant lands to a single noncompensatory use, no matter how reasonable, is to open them to every conceivable use no matter how unreasonable. Cole again summarizes the position:

I think the designation of natural areas is commendable, but so are many other activities. Any exception made for uses which do not return the fair market value to the trust would soon lead to a wholesale raid of trust lands. ${ }^{4}$

As a group, educators whose pupils derive most of the economic benefit from state lands tend to agree with Cole. For example, Arizona educators have staunchly defended the Arizona grant lands from noncompensatory use by the Arizona Highway Department. ${ }^{5}$ Their objections have been exactly those argued by Cole.

The principal user group of state lands, the ranchers, have regularly objected to trust alterations. State land grants in the West, many critics proclaim, have been manipulated solely for the benefit of the rancher; but attempts to demonstrate that this relationship has lessened the value of the trust have been less than successful. ${ }^{6}$ Logically, however, it appears reasonable that ranchers are receiving unpaid-for-benefits from state lands, and to the extent that this is true, thcy can be expected to be conservative adherents to the status quo.

Even if the rancher were not deriving unpaid-for-benefits from state lands, his conservatism is well founded. Few state lands would be used at all were it not for the rancher. Indeed, many state lands have been leased to the same operator for such extended periods of time that the lands are now a de facto portion of the estate upon which the operator is dependent for his economic survival. Any alteration of the trust which would make uncertain the operator's leasehold is understandably to be resisted

The : three groups-state trust officers, educators, and rancherstend to be conservative in approach to the state land trust concept. Even if their position is suspect as selfish, their point that the trust protects the grant lands from abuse is credible.

\section{The Revisionist}

The reasoning of the revisionist is not so orderly as is that of those who subscribe to the trustee concept. Selfishness may be as prevalent among revisionists as among trustees. To many land management agencies, it is unreasonable to pay for interests in state "public" land while in pursuit of objectives established by state law. The misconception is in viewing state grant lands as "public lands." Furthermore, those agencies which view state lands in such a light are not themselves unified. The agency which desires free use of state lands for habitat on the theory that habitat ultimately provides indirect benefit to school children is not likely to support a similar argument brought forth on behalf of highways. Nonetheless, such arguments are based on the theory that state lands are not being best utilized in terms of the overall " needs of society," a situation correctable by riddance of the major impediment-the trust.

The professional land manager in a state land management agency often sympathizes with arguments in favor of trust revision. Having

${ }^{4}$ Letter, Bert L. Cole, Commissioner of Public Lands, Washington Department of Natural Resources, to Leo Berry, Jr., Acting Commissioner, Montana Department of State Lands December 28, 1976.

5 Gladen, Frank H. 1970. 'Public School Lands in Arizona: History and Management.' Journal of the West $9,110-124$.

'See for example, Murray, Henry T. 1942. "State Land Management in Montana." Unpublished Master's Thesis. Montana State College (Bozeman).

Mosk, Sanford A. 1943. "Land Policy and Stock Raising in the Western United States.' Agricultural History 17, 14-30.

Cole, Stanley M. 1968. "A Study of Leasing Practices of Public School Lands in Colorado: Final Report." Unpublished report, Colorado State University. Rescarch in Education Report ED 022339.

Cole, Stanley M. 1966. "Relative Merits of the Sale or Retention Under Lease of Public School Lands in Colorado." Unpublished report, Colorado State University. Research in Education Report ED 010422. been schooled in multi-use concepts, he is eager to apply his knowledge and skills to a wide variety of land use practices. He understandably becomes frustrated when he discovers that state land management is largely limited to writing of leases. His arguments in favor of multi-use management are appealing but possess a fatal flaw-so far, the professional land manager has not convinced the trustee that professional judgment can be guarded from abuse.

Possibly the greatest argument in favor of revisionism is that the trust has never fulfilled its potential. To the revisionist, selection and administration of the lands has been to the exclusive benefit of limited segments of society. Specifically, state lands are a public subsidization of large ranch estates. This subsidization is so serious that lease revenues often do not equal the tax revenue had the land been disposed of rather than retained. The trust concept is appealed to today only when the land manager wishes to defend himself from innovation which would upset the inequitable and inadequate status quo. Overall, these revisionist arguments regard the trust as not only historically and presently inadequate but nearly an evil to be laid to rest once and for all.

There is abundant evidence in support of these revisionist arguments, but in fairness to the trustee, the evidence is inconclusive. Indeed, the hypothesis has been advanced that rancher-state companionability in administering state grant land reflects only the historical implementation of the most rational investment alternative for state lands. ${ }^{7}$ Even if the management history of state lands has been dismal and even if full worth has not been achieved, a management program without the trust might simply exacerbate an unfortunate situation. Management history does not necessarily provide the model for future management, so either to abandon or sustain the trust on the grounds of its historical efficacy alone is a non sequitur.

\section{Alternatives}

The debate which has surrounded the trust concept has been emotional, and while this argumentation helps identify the advocacy position of interested groups, it does not provide sufficient information to assist the decision-maker. Implicit in the original trust are goals which Congress sought to achieve in making the land grants, and which the states agreed to in accepting. Any persuasive revisionist argument must attack the trust by attacking the goals implicit in the trust. It must be shown that the goals have either been achieved or cannot be achieved under the present system. Once this has been accomplished, the revisionist has the obligation of presenting a positive program for state land management consisting of new goals and the management mechanism which will achieve the goals. It would then be the trustee's task to accept the new program or defeat the revisionist argument on the basis of its logic or social acceptability.

So far revisionist arguments have lacked widespread support and appeal because they have been fragmented, indirect, and difficult if not impossible to implement. These weaknesses in revisionist arguments will be overcome only as a solid base of theoretical, applied, and managerial research concerning the state lands is accumulated. Those with academic and applied interests in our land resources have an obligation to accumulate that needed research base.

Research may identify new goals for the state trust lands but interestingly may reveal no need to alter the trust concept. The trust accomplishes necessary protection of the grant lands but has seldom been so blind as to thwart accomplishment of social goals when truly significant nonpecuniary values are at issue. If such an hypothesis can be sustained, it would suggest that most new goals for state lands could be met at a reasonable cost with only minor adjustments in existing management tools. Certainly, without such analysis the conclusion that the trust must be either eliminated or altered is premature.

${ }^{7}$ Burnett, George Wesley. 1976. “Montana Becomes a Landlord: A Study of State Land Selection." Unpublished PhD Thesis, Iniversity of Oklahoma. 